\title{
IMPLEMENTASI METODE BALANCED SCORECARD SEBAGAI TOLOK UKUR PENGUKURAN KINERJA PADA ORGANISASI SEKTOR PUBLIK
}

\author{
Anggun Meita Anggraini ${ }^{1}$ \\ Retno Murni Sari ${ }^{2}$ \\ Nosilia Fristiani $^{3}$ \\ ${ }^{1,2,3}$ STIE Kesuma Negara Blitar \\ nosilia@stieken.ac.id
}

\begin{abstract}
Pengukuran kinerja penting dilakukan khususnya oleh organisasi sektor publik sebagai gambaran dari keberhasilan suatu strategi yang ditetapkan. Pengukuran kinerja pada organisasi sektor publik seharusnya tidak hanya berdasarkan pada aspek finansial tetapi juga nonfinansial. Kedua aspek tersebut dapat dihitung menggunakan metode Balanced Scorecard dengan 4 perspektif didalamnya. Tujuan dari penelitian ini adalah untuk menetapkan strategi yang tepat guna, terarah, seimbang dan terukur dengan menggunakan metode balanced scorecard. Penulis melakukan penelitian pada Kantor Desa Margomulyo Kecamatan Panggungrejo dengan menggunakan data APBDes dengan metode observasi, wawancara, dan dokumentasi.

Hasil penelitian menunjukkan bahwa pada perspektif keuangan sudah baik terkecuali pada Rasio kemandirian yang berada pada kisaran angka 0-25\% tergolong sangat rendah yang berarti tingkat ketergantungan terhadap pihak ekstern tergolong sangat tinggi. Dalam mengatasi rendahnya dari kondisi keuangan pada rasio kemandirian khususnya, maka Desa Margomulyo harus bisa membuat terobosan baru yang berguna untuk menurunkan tingkat ketergantungan yang masih tinggi kepada pemerintah pusat serta pinjaman daerah dengan mengoptimalkan potensi sumber-sumber Pendapatan Asli Desa serta kekayaan alam yang dimilki oleh desa
\end{abstract}

Kata kunci : Balanced Scorecard, Organisasi Sektor Publik, Pengukuran Kinerja

\section{PENDAHULUAN}

Dalam perkembangan era yang terjadi secara terus menerus saat ini, banyak sekali perubahan yang terjadi baik itu dalam organisasi bisnis maupun 
organisasi nirlaba. Perubahan tersebut terus terjadi dengan ditunjangnya kecanggihan teknologi yang tersedia. Sehingga, secara tidak langsung suatu organisasi harus segera melakukan adaptasi serta tindakan perbaikan dalam pengelolaan organisasinya. Keberhasilan dari organisasi sangat bergantung dengan kemampuannya dalam memobilitasi dan mengeksploitasi sumber daya ataupun intangible resourcesl assets (aset tak berwujud) yang memang pada kenyataannya tidaklah mudah dijabarkan kedalam dimensi keuangan. Guna untuk melihat gambaran dari suatu keberhasilan dari organisasi tersebut maka penting untuk melakukan suatu tindakan yang disebut dengan pengukuran kinerja.

Pengukuran kinerja adalah salah satu faktor terpenting bagi organisasi swasta maupun publik. Hal ini dikarenakan hasil dari pengukuran tersebut dapat digunakan sebagai bahan evaluasi dan juga sebagai tolok ukur dalam memonitor berhasil atau tidaknya stretegi kinerja yang telah dilaksanakan suatu organisasi termasuk juga pada organisasi sektor publik atau organisasi nirlaba. Organisasi sektor publik atau organisasi nirlaba merupakan organisasi yang berfokus pada pelayanan terhadap publik serta mengelola dana publik. Dalam hal ini yang termasuk kedalam organisasi sektor publik adalah organisasi Pemerintahan.

Dalam pelaksanaan amanah yang diberikan kepada instansi pemerintahan, sering bermunculan berbagai komentar dari masyarakat mengenai keberhasilan atau tidaknya amanah tersebut dalam menunjukkan kepedulian serta harapan publik yang direspon dengan semestinya. Namun, kinerja dari instansi yang dilaksanakan oleh badan pengelola dan para pejabat pemerintahan sering berbeda dengan harapan para masyarakat. Hal ini dikarenakan belum adanya sistem pengukuran kinerja formal yang menginformasikan tingkat keberhasilan dari suatu instansi pemerintah. Oleh karena hal tersebut, maka jadilah alasan untuk memperbaiki indikator keberhasilan dari instansi pemerintahan agar dapat mencerminkan kinerja yang sesungguhnya. Tingkat keberhasilan dari sebuah kinerja harus diukur tidak hanya pada input dari sebuah program instansi tetapi juga harus lebih ditekankan pada output, process, manfaat, serta dampak dari program tersebut bagi kesejahteraan masyarakat. Dengan adanya suatu pengukuran kinerja maka tingkat keberhasilan dari sebuah kinerja yang dilakukan oleh instansi pemerintah dapat terlihat jelas.

Kinerja organisasi sektor publik khususnya dalam Pemerintahan Desa, menjadi hal yang penting setelah dengan diberlakukannya Undang-Undang Nomor 6 Tahun 2014 tentang Desa yang dimana memperlihatkan iktikad negara untuk mengotonomikan desa dalam segala bentuk kemandirian pemerintahan desa yaitu seperti anggaran desa, pemilihan umum bagi calon pemimpin desa, DPRD desa, dan kemandirian pembuatan peraturan desa semacam Perda, yang mengakibatkan daerah otonom NKRI menjadi provinsi, kabupaten atau kota, dan desa.

Sejalannya dengan era otonomi daerah yang menitik beratkan pada upaya pemberdayaan masyarakat, maka sebagai lembaga terdepan dalam sistem pemerintahan Republik Indonesia, Pemerintah Desa mempunyai peranan penting karena desa dijadikan sebagai salah satu ujung tombak organisasi pemerintah dalam pencapaian keberhasilan dalam urusan pemerintahan yang berasal dari Pemerintah Pusat dan Pemerintah Desa adalah yang lebih dekat 
serta langsung berhadapan dengan masyarakat, sehingga berhasil atau tidaknya suatu pencapaian sasaran pelaksanaan otonomi daerah bergantung pada seberapa baikkah suatu kinerja pemerintahan desa dalam menerapkan peranan, fungsi, wewenang sebagai perangkat yang melayani masyarakat terdepan. Hal ini juga terkait dengan Pemerintah Desa yang ada di Margomulyo yang kantornya terletak di Jalan Protokol no.40, Desa Margomulyo, Kecamatan Panggungrejo, Kab.Blitar.

Kantor Desa Margomulyo merupakan salah satu Pemerintah Desa dari Kabupaten Blitar yang bertugas sebagai wadah pelayanan publik kepada masyarakat Desa Margomulyo khususnya. Dalam pemberian pelayanan, Pemerintah Desa Margomulyo menyusun suatu visi, misi, tujuan, sasaran, dan indikator atau strategi keberhasilan. Dalam hal ini, indikator keberhasilan tersebut tidaklah hanya dari segi finansial namun juga dari segi non finansial seperti kepuasan masyarakat, proses bisnis internal, serta pembelajaran dan pertumbuhan. Hal ini dikarenakan, kinerja dari sektor publik bersifat multidimensional. Oleh karena itu, tidak ada indikator tunggal yang dapat dipakai dalam memperlihatkan kinerja secara komprehensif.

Selanjutnya, indikator-indikator keberhasilan tersebut dapat digunakan sebagai bahan evaluasi, memonitor pelaksanaan kinerja yang berfokus pada tingkat mencapai tujuan serta sasaran program unit kerja yang sesuai dengan visi dan misinya yang selanjutnya dituangkan dalam perencanaan strategis sehingga akan dapat meningkatkan efisiensi dan efektivitas dalam pemberian pelayanan terhadap masyarakat desa. Dalam memonitor serta mengevaluasi kinerja yang dihasilkan secara berkesinambungan, maka pihak manajemen membutuhkan sebuah alat bantu yang digunakan sebagai alternatif pengukuran kinerjanya dan untuk mengambil keputusan yaitu dengan menggunakan Balanced Scorecard yang lebih komprehensif, akurat dan terukur.

Balanced Scorecard merupakan sebuah metode dari pengukuran kinerja yang berusaha menyeimbangkan antara aspek finansial dan nonfinansial. Hal ini juga terkait dengan upaya pemerintah dalam pencitaan penyelenggaraan yang lebih tertata dan lebih baik lagi khususnya pada Pemerintah Desa dengan berlandaskan good governance. Pada organisasi Pemerintah Desa juga ditantang untuk dapat memenuhi harapan dari berbagai kelompok stakeholder (perangkat, penerima layanan, masyarakat).

Dengan adanya dan diberlakukannya UU Nomor 6 Tentang Desa, maka dapat diketahui bahwa setiap desa akan menerima anggaran dari APBN dengan jumlah cukup besar yang kemudian untuk dikelola. Oleh karena itu, sebagai organisasi pengguna dana publik yang cukup besar, Pemerintah Desa dituntut untuk meningkatkan kinerjanya dalam hal mengelola keuangan desa yang bersifat transparan dan akuntabel, serta dalam hal pelayanan dan peningkatan kesejahteraan masyarakat desa. Sehingga, sebuah pengukuran kinerja yang mampu mengukur secara menyeluruh atau komprehensif sangat perlu dilakukan pada Pemerintah Desa khususnya pada Pemerintah Desa Margomulyo. Hal ini dikarenakan Pemerintah Desa berperan sebagai pondasi bagi Negara. Apabila kinerja dari Pemerintah Desa tidak terlaksana dengan baik, maka akan berpengaruh pada hasil kinerja tersebut, dan tidak akan mewujudkan suatu pelayanan yang sesuai keinginan bagi masyarakat. Berdasarkan uraian maka bagaimana menganalisis strategi yang tepat guna, 
terarah, seimbang dan terukur dengan menggunakan metode balanced scorecard sebagai tolok ukur pengukuran kinerja pada sektor publik?

\section{TINJAUAN PUSTAKA}

\section{A. Definisi Balanced Scorecard}

Menurut (Mulyadi,2009) Balanced Scorecard yaitu serangkaian alat manajemen modern yang dirancang guna mengembangkan kapasitas dari perusahaan dalam rangka meningkatkan kinerja dari keuangan yang menakjubkan secara berkelanjutan.

B. Keunggulan Balanced Scorecard

Terdapat keunggulan dua aspek dari Balanced Scorecard menurut (Mulyadi, 2009:14), yaitu: (1)Kualitas pelayanan dapat ditingkatkan secara signifikan. (2) Kualitas dari pengelolaan kinerja personel meningkat

C. Faktor Penghambat Dalam Pengimplementasian Rencana Bisnis Strategis Balanced Scorecard Menurut (Luis 2009: 9) terdapat faktor penghambat dalam pengimplementasian rencana bisnis strategis Balanced Scorecard yaitu sebagai berikut:

(1) Hambatan pada Visi

(2) Hambatan pada Pelaku

(3) Hambatan pada Manajemen

(4) Hambatan pada Sumber Daya

D. Pengukuran Kinerja

(1) Definisi Kinerja

Kinerja atau performance adalah suatu bentuk penggambaran dari keberhasilan pencapaian pelaksanaan suatu program kegiatan operasional perusahaan yang tertuang melalui perencanaan strategis organisasi sebagai perwujudan dari sasaran, tujuan, visi serta misi organisasi tersebut (Moeheriono, 2009:60).

(2) Standar Kinerja

Menurut Dally (2010:35), standar kinerja adalah suatu pernyataan dalam bentuk kuantitatif sebagai hasil dari ukuran tingkat kinerja yang dicapai dan sesuai dengan harapan. Oleh karena itu, maka suatu standar

E. Organisai Sektor Publik

Menurut Halim dan Syam (2013:10) yang dimaksud dengan organisasi sektor publik adalah perkumpulan dari beberapa orang dengan memiliki suatu tujuan dengan aktivitas peyedia barang dan jasa guna memenuhi kebutuhan publik atau masyarakat. Kesimpulan dari kedua definisi tersebut adalah bahwa organisasi sektor publik merupakan sebuah organisasi yang mempunyai tanggungjawab untuk melayani segala kebutuhan dari masyarakat.

\section{F. Desa dan Pemerintah Desa}

(1)Desa

Desa menurut Rusmianto dan Yuliansyah (2018:3) menyatakan bahwa Desa adalah sebagai kesatuan masyarakat hukum yang mempunyai susunan asli berdasarkan hak asal-usul yang bersifat istimewa. Landasan pemikiran dalam mengenai Pemerintahan Desa adalah 
keanekaragaman, partisipasi, otonomi asli, demokratisasi dan pemberdayaan masyarakat.

(2) Pemerintahan Desa

Berdasarkan Pasal 25 Undang-Undang Nomor 6 tahun 2014 tentang Desa, dijelaskan bahwa "Pemerintah Desa adalah Kepala Desa atau yang disebut dengan nama lain dan yang dibantu oleh perangkat desa atau yang disebut dengan nama lain."

\section{METODE PENELITIAN}

\section{A. Metode Penelitian}

1. Observasi

Metode pengumpulan data dengan cara mendatangi lokasi secara langsung untuk melakukan pengamatan yang meliputi merekam, menghitung, mengukur, dan mencatat peristiwa yang terjadi pada objek yang diteliti.

2. Wawancara

Proses tanya jawab dengan responden secara langsung dengan perangkat desa Margomulyo dengan beberapa pertanyaan yang sesuai dengan kebutuhan penelitian yang hasilnya akan dijabarkan pada perspektif proses bisnis internal.

3. Dokumentasi

Dokumentasi yaitu metode pengumpulan data yang dimana penulis mengumpulkan data berupa laporan keuangan APBDes tahun anggaran 2017-2019 yang selanjutnya yang akan

Digunakan untuk menilai perspektif keuangan.

\section{HASIL PENELITIAN DAN PEMBAHASAN}

\section{A. Gambaran Umum Tempat Penelitian}

\section{Kondisi Geografis dan Demografi Desa Margomulyo}

Desa Margomulyo merupakan salah satu desa yang berada di Kecamatan Panggungrejo Kabupaten Blitar. Secara geografis Desa Margomulyo terletak pada posisi $7^{\circ} 21^{\prime}-7^{\circ} 31^{\prime}$ Lintang Selatan dan $110^{\circ} 10^{\prime}-111^{\circ} 40^{\prime}$ Bujur Timur. Topografi ketinggian desa Margomulyo ini yaitu sekitar $156 \mathrm{~m}$ di atas permukaan air laut berupa daratan sedang. Apabila diukur dari permukaan laut maka Desa Margomulyo berada di ketinggian antara 300 - 325 diatas permukaan air laut.

2. Struktur Organisasi Dan Uraian Jabatan Kantor Desa Margomulyo Berikut adalah bagan dari struktur organisasi pada Kantor Desa Margomulyo. 


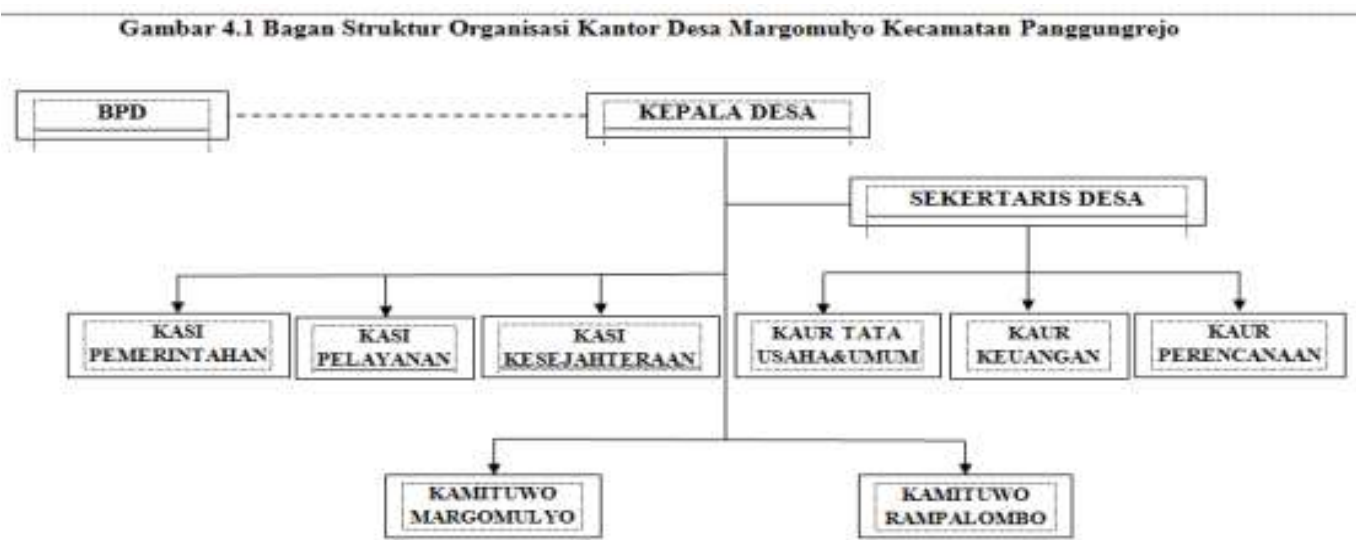

Sumber: Kantor DesaMargomulyo,2020

\section{B. Analisis Data}

Pengukuran kinerja yang dilakukan pada Kantor Desa Margomulyo adalah dengan menggunakan metode Balanced Scorecard dengan empat perspektif didalamnya. Berikut merupakan hasil perhitungan dari masing-masing perspektif tersebut:

\section{Perspektif Keuangan}

Dihitung dengan menggunakan analisis rasio kemandirian keuangan, rasio efektifitas, rasio efisiensi, dan rasio aktivitas.

\section{a. Rasio Ekonomis}

\section{Tabel 4.2}

Rasio Ekonomis Pemerintah Desa Margomulyo Tahun Anggaran 2017-2019

\begin{tabular}{|c|c|c|c|c|l|}
\hline Th & $\begin{array}{c}\text { Realisasi } \\
\text { Belanja } \\
(\mathbf{R p})\end{array}$ & $\begin{array}{c}\text { Anggaran } \\
\text { Belanja } \\
(\mathbf{R p})\end{array}$ & $\begin{array}{c}\text { Rasio } \\
\text { Ekonomis } \\
(\boldsymbol{\%})\end{array}$ & $\begin{array}{l}\text { Peningkatan/Penurunann } \\
\mathbf{\%}\end{array}$ & Kriteria \\
\hline 2017 & 1.173 .228 .243 & 1.298 .033 .759 & 90,38 & - & Ekonomis \\
\hline 2018 & 1.591 .371 .623 & 1.593 .871 .623 & 99,84 & 9,46 & Ekonomis \\
\hline 2019 & 1.382 .853 .000 & 1.398 .444 .068 & 98,88 & 0.96 & Ekonomis \\
\hline
\end{tabular}

Sumber: Laporan Realiasi APBDes Pemerintah Desa Margomulyo (Data Diolah, 2020)

\section{b. Rasio Kemandirian Keuangan}

\section{Tabel 4.3}

Rasio Kemandirian Keuangan Pemerintah Desa Margomulyo Tahun Anggaran 2017-2019

\begin{tabular}{|c|c|c|c|c|}
\hline Th & $\begin{array}{c}\text { PADes } \\
(\mathbf{R p})\end{array}$ & $\begin{array}{c}\text { Pendapatan Transfer } \\
(\mathbf{R p})\end{array}$ & $\begin{array}{c}\text { Rasio } \\
\text { Kemandirian } \\
(\boldsymbol{\%})\end{array}$ & $\begin{array}{c}\text { Peningkatan/ } \\
\text { Penurunan } \\
(\boldsymbol{\%})\end{array}$ \\
\hline 2017 & 89.500 .000 & 1.208 .533 .759 & 7,40 & - \\
\hline 2018 & 89.700 .000 & 1.376 .752 .576 & 6,51 & $(0,89)$ \\
\hline 2019 & $91.021 .727,63$ & $1.304 .722 .959,60$ & 6,97 & 0,54 \\
\hline
\end{tabular}

Sumber: Laporan Realiasi APBDes Pemerintah Desa Margomulyo (Data Diolah, 2020) 


\section{c. Rasio Efektivitas}

\section{Tabel 4.4}

Rasio Efektivitas Keuangan Pemerintah Desa Margomulyo Tahun Anggaran 2017-2019

\begin{tabular}{|c|c|c|c|c|c|}
\hline Th & $\begin{array}{c}\text { Realisasi } \\
\text { PADes } \\
(\mathbf{R p})\end{array}$ & $\begin{array}{c}\text { Anggaran } \\
\text { PADes } \\
(\mathbf{R p})\end{array}$ & $\begin{array}{c}\text { Rasio } \\
\text { Efektifitas(\%) }\end{array}$ & $\begin{array}{c}\text { Peningkatan/ } \\
\text { Penurunan } \\
(\boldsymbol{\%})\end{array}$ & Kriteria \\
\hline 2017 & 89.500 .000 & 89.500 .000 & 100 & - & Efektif \\
\hline 2018 & 89.700 .000 & 89.700 .000 & 100 & 0 & Efektif \\
\hline 2019 & $91.021 .727,63$ & 89.700 .000 & 101 & 1 & Sangat efektif \\
\hline
\end{tabular}

Sumber: Laporan Realiasi APBDes Pemerintah Desa Margomulyo (Data Diolah, 2020)

\section{d. Rasio Efisiensi}

Tabel 4.5

Rasio Efisiensi Keuangan Pemerintah Desa Margomulyo Tahun Anggaran 2017-2019

\begin{tabular}{|c|c|c|c|c|c|}
\hline Thn & $\begin{array}{c}\text { Realisasi } \\
\text { Belanja } \\
(\mathbf{R p})\end{array}$ & $\begin{array}{c}\text { Realisasi } \\
\text { Pendapatan } \\
(\mathbf{R p})\end{array}$ & $\begin{array}{c}\text { Rasio } \\
\text { Efisiensi(\%) }\end{array}$ & $\begin{array}{c}\text { Peningkatan/ } \\
\text { Penurunan }\end{array}$ & Kriteria \\
\hline 2017 & 1.173 .228 .243 & 1.298 .033 .759 & 90.38 & - & $\begin{array}{c}\text { Kurang } \\
\text { Efisien }\end{array}$ \\
\hline 2018 & 1.591 .371 .623 & 1.469 .066 .107 & 108,32 & $17,94 \%$ & $\begin{array}{c}\text { Tidak } \\
\text { Efisien }\end{array}$ \\
\hline 2019 & 1.382 .853 .000 & $1.395 .744 .687,13$ & 99,07 & $(9.25 \%)$ & $\begin{array}{c}\text { Kurang } \\
\text { Efisien }\end{array}$ \\
\hline
\end{tabular}

Sumber: Laporan Realiasi APBDes Pemerintah Desa Margomulyo (Data Diolah, 2020)

2. Perspektif Pelanggan .

\section{a. Uji Validitas}

Penelitian ini menggunakan sampel sebesar $\mathrm{n}=98$, maka diperoleh $\mathrm{df}=$ $98-2=96$. Dengan $\alpha=5 \%$

didapatkan $\mathrm{r}$ tabel sebesar 0,1986. Butir pertanyaan dikatakan valid apabila $\mathrm{r}$ hitung $>\mathrm{r}$ tabel.

Tabel 4.8

Hasil Uji Validitas Kepuasan Pelanggan (Masyarakat)

\begin{tabular}{|c|c|c|c|c|}
\hline Variabel & Item & R Hitung & R Tabel & Keterangan \\
\hline \multirow{14}{*}{$\begin{array}{l}\text { Kepuasan } \\
\text { Pelanggan }\end{array}$} & P1 & 0.848 & 0.1986 & Valid \\
\hline & $\mathrm{P} 2$ & 0.671 & 0.1986 & Valid \\
\hline & P3 & 0.872 & 0.1986 & Valid \\
\hline & $\mathrm{P} 4$ & 0.773 & 0.1986 & Valid \\
\hline & P5 & 0.896 & 0.1986 & Valid \\
\hline & P6 & 0.858 & 0.1986 & Valid \\
\hline & P7 & 0.889 & 0.1986 & Valid \\
\hline & P8 & 0.877 & 0.1986 & Valid \\
\hline & P9 & 0.829 & 0.1986 & Valid \\
\hline & P10 & 0.853 & 0.1986 & Valid \\
\hline & P11 & 0.684 & 0.1986 & Valid \\
\hline & P12 & 0.818 & 0.1986 & Valid \\
\hline & P13 & 0.869 & 0.1986 & Valid \\
\hline & P14 & 0.930 & 0.1986 & Valid \\
\hline
\end{tabular}

Sumber: Data Diolah, 2020 


\section{b. Uji Reliabilitas}

Kriteria dari pengujian reliabilitas ini menyatakan bahwa apabila koefisien Cronbach's Alpha > 0,60 maka item dari kuesioner tersebut dinyatakan reliabel dalam mengukur variabel yang diukurnya

Tabel 4.9

Hasil Uji Reliabilitas Kepuasan Pelanggan (Masyarakat)

\begin{tabular}{|r|r|r|}
\hline \multicolumn{2}{|c|}{ Cronbach's Alpha } & \multicolumn{2}{c|}{$\begin{array}{c}\text { Cronbach's Alpha Based on } \\
\text { Standardized Items }\end{array}$} & \multicolumn{1}{c|}{ N of Items } \\
\hline .961 & .967 & 14 \\
\hline
\end{tabular}

Sumber: Data Diolah, 2020.

\section{c. Indeks Kepuasan Pelanggan}

Berdasarkan dari 98 kusioner yang disebar dengan 14 butir pernyataan yang dianggap valid maka standar minimal yang ditetapkan adalah didasarkan pada skala yang digunakan untuk pengolahan data sebagai berikut:

$$
\begin{aligned}
\text { IKMax } & =\text { TP } \times \text { R } \times \text { EXMax } \\
& =14 \times 98 \times 5 \\
\text { IKMax } & =6860 \\
\text { IKmin } & =\text { TP } \times \text { R } \times \text { EXMin } \\
& =14 \times 98 \times 1 \\
\text { IKmin } & =1372 \\
\text { Interval } & =\frac{\text { IKMax-IKMin }}{\text { Jumlah Skala }} \\
& =\frac{6860-1372}{5} \\
& =1098
\end{aligned}
$$

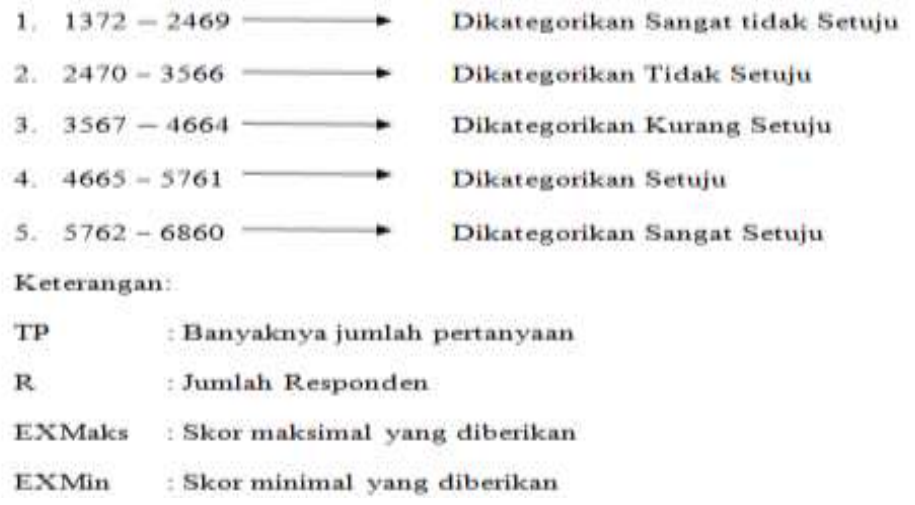

Tabel 4. 10

Total Nilai Kuesioner Kepuasan Pelanggan (Masyarakat)

Total Nilai Kuesioner Kepuasan Pelanggan (Masyarakat)

Sumber: Data diolah, 2020.

\section{Perspektif Proses Bisnis Internal}

\section{a. Inovasi}

Adapun inovasi dari Pemerintah Desa Margomulyo yaitu: (1)Membentuk aparatur pemerintah desa yang memiliki kapasitas dan skill yang tinggi dalam melayani masyarakat sehingga tercipta pemerintahan desa yang efektif dan 
efisien, (2)Membangun pelayanan dasar yang memadai serta berkualitas yakni meliputi pendidikan, kesehatan, tempat tinggal yang layak, dan lingkungan hidup, (3)Membangun infrastruktur pedesaan yang mampu mendukung aktifitas ekonomi, sosial dan budaya, (4) Mendorong terciptanya kegiatan ekonomi yang berkualitas dan berkelanjutan dapat dinikmati oleh seluruh masyarakat yang berdaya saing serta melakukan penerapan Iptek, (5) Membangun ekonomi masyarakat melalui usaha pertanian, peternakan, dan jasa. (6) Menciptakan terwujudnya kualitas ketertiban dan ketentraman masyarakat desa.

\section{b. Sarana dan Prasarana Kantor Desa Margomulyo}

Berikut merupakan asset berupa kondisi dari sarana dan prasarana Kantor Desa Margomulyo:

\begin{tabular}{|c|l|c|c|}
\hline \multirow{2}{*}{ No } & \multicolumn{1}{|c|}{ Sarana dan Prasarana } & \multicolumn{2}{|c|}{ Keterangan } \\
\cline { 3 - 4 } & & Ada/Tidak & Baik/Rusak \\
\hline $\mathbf{1}$ & Bangunan Balai Desa & Ada & Baik \\
\hline $\mathbf{2}$ & Meja & Ada & Baik \\
\hline $\mathbf{3}$ & Kursi & Ada & Baik \\
\hline $\mathbf{4}$ & Mesin Tik & Ada & Baik \\
\hline $\mathbf{5}$ & Komputer PC & Ada & Baik \\
\hline $\mathbf{6}$ & Laptop & Ada & Baik \\
\hline $\mathbf{7}$ & Kalkulator & Ada & Kurang Baik \\
\hline $\mathbf{8}$ & Almari Arsip & Ada & Kurang Baik \\
\hline $\mathbf{9}$ & Papan Penyaji Data & Ada & Baik \\
\hline $\mathbf{1 0}$ & Ruang Kepala Desa / & Ada & Baik \\
\hline $\mathbf{1 1}$ & Aparat Desa & & Baik \\
\hline $\mathbf{1 2}$ & Wifi & Ada & Baik \\
\hline $\mathbf{1 3}$ & Mushola & Ada & Ada \\
\hline
\end{tabular}

Sumber: Kantor Desa Margomulyo, 2020.

\section{c. Proses Operasional dan Teknologi}

Dengan kemajuan era digital yang dimana perkembangan teknologi sangat pesat dan dengan adanya teknologi ini maka segala sesuatu yang terkait dengan penataan administrasi desa akan lebih mudah diatur. Dalam hal ini, Kantor Desa Margomulyo juga telah mengikuti perubahan yang merupakan dampak dari kemajuan teknologi tersebut dengan menggunakan aplikasi antara lain yaitu SISKEUDES (Sistem Keuangan Desa), SIMKAD, OSS, SIPEDE (Sistem Informasi Pembangunan Desa), OMSPAN (Online Monitoring Sistem Perbendaharaan dan Anggaran Negara), ADMINDUK (Adminitrasi Kependudukan).

\section{Perspektif Pembelajaran dan Pertumbuhan}

\section{a. Uji Validitas}

Uji validitas ini dilakukan dengan mengkorelasikan setiap skor item dengan skor total dengan menggunakan teknik Korelasi Pearson (Product Moment). Item kuesioner dapat digunakan sebagai alat pengumpul data dan dapat dinyatakan valid apabila $r_{\text {hitung }}>r_{\text {tabel }}$ dengan $\mathrm{df}=\mathrm{n}-2$ yaitu $9-$ $2=7$. Berikut adalah tabel ringkasan dari hasil pengujian validitas pada beberapa instrument pertanyaan: 
Tabel 4. 14

Hasil Uji Validitas Variabel Kinerja

\begin{tabular}{|c|c|c|c|c|}
\hline Variabel & Item & R hitung & R tabel & Keterangan \\
\hline \multirow{3}{*}{ Kinerja } & P1 & $\mathbf{0 . 9 8 1}$ & $\mathbf{0 . 5 8 2}$ & Valid \\
\cline { 2 - 5 } & P2 & $\mathbf{0 . 8 4 6}$ & $\mathbf{0 . 5 8 2}$ & Valid \\
\cline { 2 - 5 } & P3 & $\mathbf{0 . 9 0 1}$ & $\mathbf{0 . 5 8 2}$ & Valid \\
\hline
\end{tabular}

Sumber: Data diolah, 2020.

Tabel 4.15

Hasil uji validitas Variabel Kepemimpinan

\begin{tabular}{|c|c|c|c|c|}
\hline Variabel & Item & R hitung & R tabel & Keterangan \\
\hline \multirow{2}{*}{$\begin{array}{c}\text { Kepemimpi } \\
\text { nan }\end{array}$} & $\mathrm{P} 1$ & $\mathbf{0 . 8 7 5}$ & $\mathbf{0 . 5 8 2}$ & Valid \\
\cline { 2 - 5 } & $\mathrm{P} 2$ & $\mathbf{0 . 9 2 9}$ & $\mathbf{0 . 5 8 2}$ & Valid \\
\cline { 2 - 5 } & $\mathrm{P} 3$ & $\mathbf{0 . 8 1 2}$ & $\mathbf{0 . 5 8 2}$ & Valid \\
\hline
\end{tabular}

Sumber: Data diolah, 2020.

Tabel 4.16

Hasil uji validitas Variabel Motivasi

\begin{tabular}{|c|c|c|c|c|}
\hline Variabel & Item & R hitung & R tabel & Keterangan \\
\hline \multirow{3}{*}{ Motivasi } & P1 & $\mathbf{0 . 7 8 3}$ & $\mathbf{0 . 5 8 2}$ & Valid \\
\cline { 2 - 5 } & P2 & $\mathbf{0 . 9 5 5}$ & $\mathbf{0 . 5 8 2}$ & Valid \\
\cline { 2 - 5 } & $\mathrm{P} 3$ & $\mathbf{0 . 7 8 8}$ & $\mathbf{0 . 5 8 2}$ & Valid \\
\hline
\end{tabular}

Sumber: Data diolah, 2020.

Tabel 4.17

Hasil uji validitas Variabel Lingkungan Kerja

\begin{tabular}{|c|c|c|c|c|}
\hline Variabel & Item & R hitung & R tabel & Keterangan \\
\hline \multirow{3}{*}{ Lingkungan Kerja } & P1 & $\mathbf{0 . 7 8 4}$ & $\mathbf{0 . 5 8 2}$ & Valid \\
\cline { 2 - 5 } & $\mathrm{P} 2$ & $\mathbf{0 . 7 8 4}$ & $\mathbf{0 . 5 8 2}$ & Valid \\
\cline { 2 - 5 } & $\mathrm{P} 3$ & $\mathbf{0 . 8 9 4}$ & $\mathbf{0 . 5 8 2}$ & Valid \\
\hline
\end{tabular}

Sumber: Data diolah, 2020.

\section{a. Uji Reliabilitas Kepuasan Perangkat Desa}

Tabel 4.18

Hasil Uji Reliabilitas Kepuasan Perangkat Desa

\begin{tabular}{|l|c|c|c|}
\hline \multicolumn{1}{|c|}{ Indikator } & Cronbach's Alpha & Nilai Kritis & Keterangan \\
\hline Kinerja & 0.897 & 0,60 & Reliabel \\
\hline Kepemimpinan & 0.844 & 0,60 & Reliabel \\
\hline Motivasi & 0.797 & 0,60 & Reliabel \\
\hline Kondisi Lingkungan Kerja & 0.750 & 0,60 & Reliabel \\
\hline
\end{tabular}

Sumber: Data Diolah, 2020

\section{b. Indeks Kepuasan Perangkat Desa}

Berdasarkan dari 9 kusioner yang disebar dengan 4 variabel dengan setiap variabel berisi 3 butir pernyataan yang dianggap valid, maka standar minimal yang ditetapkan adalah didasarkan pada skala yang digunakan untuk pengolahan data sebagai berikut:

$$
\begin{aligned}
& \begin{aligned}
\text { IKMax } & =\text { TP } \times \text { R } \times \text { EXMax } \\
& =12 \times 9 \times 5 \\
\text { IKMax } & =540 \\
\text { IKmin } & =\text { TP } \times \text { R } \times \text { EXMin } \\
& =12 \times 9 \times 1
\end{aligned} \\
& \text { IKmin }=108
\end{aligned}
$$




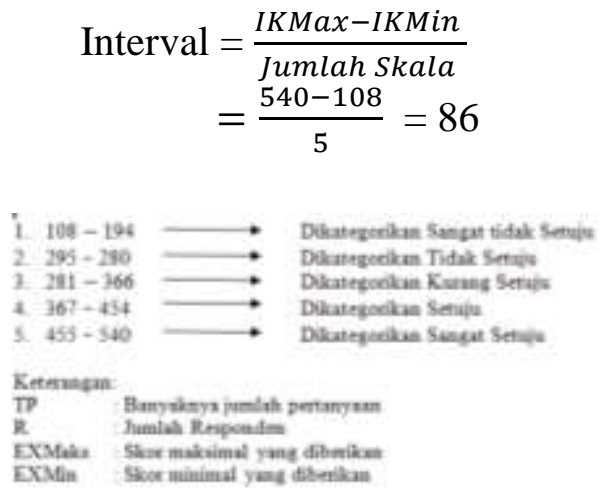

Tabel 4. 19

Total Nilai Kepuasan Perangkat Desa

\section{Sumber: Data Diolah, 2020.}

\begin{tabular}{c|c}
$\begin{array}{c}\text { Total Kepuasan } \\
\text { Perangkat Desa } \\
\text { Margomulyo }\end{array}$ & 487 \\
\hline
\end{tabular}

\section{a. Pelatihan Aparat/Perangkat Desa}

Pelatihan teknis, dilakukan setiap 1 bulan sekali atau 3 bulan sekali misalnya, bimtek SIPADES (Sistem Pengelolaan Aset Desa) yang dilaksanakan oleh Dinas Pemberdayaan Masyarakat dan Desa Kabupaten Blitar guna mewujudkan tertibnya administrasi pengelolaan aset desa, bimtek ADMINDUK (Administrasi Kependudukan) yang diselenggarakan oleh Dinas Penduduk, bimtek SISKEUDES (Sistem Keuangan Desa), dan lain sebagainya.

\section{KESIMPULAN DAN SARAN}

\section{A. KESIMPULAN}

Berdasarkan penelitian yang telah dilakukan pada Kantor Desa Margomulyo dengan menggunakan Balanced Scorecard maka penulis menyimpulkan bahwa:

1. Jika dilihat dari perspektif keuangan yang dinilai dengan menggunakan rasio ekonomis, rasio kemandirian, rasio efektifitas, dan rasio efisiensi. Secara keseluruhan hasil yang diperoleh tergolong sudah sesuai dengan standart yang ditentukan walaupun juga masih ada yang perlu diperbaiki terutama pada rasio kemandiriannya. Hal ini dikarenakan lebih besarnya nilai penerimaan pendapatan lain yang berasal dari Alokasi Dana Desa, Dana Desa, Bantuan Keuangan dari Provinsi dan Kabupaten, Bagi Hasil Pajak dan Retribusi daripada penerimaan yang berasal dari Pendapatan Asli Desa menjadi penyebab dari rendahnya rasio ini dan berarti tingkat ketergantungan kepada pemerintah pusat lebih dominan daripada kemandirian dari Desa itu sendiri selain itu yang menjadi penyebabnya adalah karena sumber-sumber keuangan potensial negara adalah milik dari pemerintah pusat.

2. Dari perspektif pelanggan, hasil yang diperoleh dari penyebaran kuesioner kepada masyarakat menghasilkan nilai hasil yang kurang memuaskan. Hal ini disebabkan dari segi fasilitas maupun kemampuan perangkat Desa Margomulyo dalam hal melayani masih cukup lamban.

3. Hasil pengukuran kinerja berdasarkan pada perspektif proses bisnis dan Internal dapat diketahui bahwa Pemerintah Desa Margomulyo mempunyai inovasi yang baik di bidang pelayanan maupun pembangunannya. Sarana dan 
prasarana yang tersedia sudah cukup memadai terkecuali pada bangunan Balai Desa gedung pertemuan/ aula sebagai wadah untuk kegiatan rembuk desa/ musyawarah desa masih dalam keadaan kurang baik, dan untuk penggunaan teknologi yang dapat mempermudah serta mempersingkat waktu dalam proses operasionalnya, serta Pemerintah Desa Margomulyo yang sudah taat dengan peraturan yang diberlakukan.

4. Hasil pengukuran kinerja berdasarkan pada perspektif pertumbuhan dan pembelajaran yang diukur dengan menyerbar kuesioner ke perangkat desa yang ditinjau dari segi kinerja, kepemimpinan, motivasi dan lingkungan kerja menghasilkan nilai yang sangat memuaskan dan untuk pelatihan aparat/perangkat desa juga menghasilkan yang baik.

\section{B. SARAN}

1. Dalam mengatasi rendahnya dari kondisi keuangan pada rasio kemandirian khususnya, maka Desa Margomulyo harus bisa membuat terobosan baru yang berguna untuk menurunkan tingkat ketergantungan yang masih tinggi kepada pemerintah pusat serta pinjaman daerah dengan mengoptimalkan potensi sumber-sumber Pendapatan Asli Desa (PADes) serta kekayaan alam yang dimilki oleh desa misalnya dengan membangun desa pariwisata, pengadaan pasar murah, dan lain sebagainya sebagai upaya meendongkrak peningkatan Pendapatan Asli Desa (PADes) menuju pemerintahan yang mandiri.

2. Pada perspektif pelanggan, para aparat/perangkat desa diharapkan untuk selalu meningkatkan mutu serta kualitas pelayanannya kepada masyarakat sehingga kepuasan masyarakat akan berada pada posisi baik atau puas dengan memperbaiki kekurangan berdasarkan keluhan yang disampaikan oleh masyarakat.

3. Untuk proses bisnis internal, pengecekan kelayakan fasilitas pada Kantor Desa Margomulyo perlu dilakukan supaya proses bisnis yang sudah berada pada posisi yang baik dapat terus ditingkatkan.

4. Untuk kinerja pertumbuhan dan pembelajaran pada Kantor Desa Margomulyo sudah baik dan sudah seharusnya untuk dipertahankan serta ditingkatkan dengan adanya pelatihan serta pemahaman bagi aparat/perangkat desa dalam menjalankan kewajibannya sebagai penyedia jasa layanan yang berkualitas dengan berpedoman pada standar baku (SOP) dan Standar Pelayanan Minimal (SPM).

5. Sebagai masyarakat sudah seharusnya mendukung kebijakan yang dibuat oleh Pemerintah Desa yang bersifat membangun. Maka, pemerintah Desa Margomulyo harus mengembangkan sumber daya yang dimiliki secara maksimal dengan tujuan untuk tercapainya pertumbuhan ekonomi.

\section{DAFTAR PUSTAKA}

Anthony, Robert N dan Vijay Govindarajan. 2012. Management Control System system Pengendalian Manajemen. Buku 2. Salemba Empat. Jakarta.

Astriana, Risky. 2011. Penerapan Analisis Balanced Scorecard Sebagi Alternatif Untuk Mengukur Kinerja Perusahaan Pada PDAM Kota Blitar Tahun 20062010. Skripsi. Program Studi Akuntansi STIE Kesuma Negara Blitar. 
Dally, Dadang. 2010. Balanced Scorecard Suatu Pendekatan dalam Implementasi Manajemen Berbasis Sekolah. Bandung: PT Remaja Rosdakarya.

Effendi, Rizal. 2012. Pengukuran Kinerja Sektor Publik Dengan Menggunakan Balanced Scorecard (Studi Kasus Kanwil DJP Sumsel dan Kep. Babel). Jurnal Ilmiah STIE MDP 1(2) : 67-73. Universitas Tridinanti. Palembang.

Halim, Abdul dan Syam Kusufi. 2013. Akuntansi Sektor Publik. Salemba Empat. Jakarta.

Halim, Abdul. 2012. Akuntansi Keuangan Daerah. Salemba Empat. Jakarta.

Laporan Penyelenggaran Pemerintah Desa (LPPD) Tahun Anggaran 2018 Desa Margomulyo Kecamatan Panggungrejo. Blitar

Luis, Suwardi dan Prima A. Biromo. 2009. Step by Step in Cascading Balanced Scorecard to Functional Scorecards. Jakarta: PT. Gramedia Pustaka Utama.

Mahsun, Mohamad. 2016. Pengukuran Kinerja Sektor Publik. BPFE. Yogyakarta.

Mardiasmo. 2009. Akuntansi Sektor Publik. Andi. Yogyakarta.

Moeheriono. 2009. Pengukuran Kinerja Berbasis Kompetensi. Indonesia: Ghalia.

Mulyadi. 2009. Sistem Terpadu Pengelolaan Kinerja Personel Berbasis Balanced Scorecard. Sekolah tinggi Ilmu Manajemen YKPN. Yogyakarta.

Permendesa Nomor 1 Tahun 2015 tentang Pedoman Kewenangan Berdasarkan Hak Asal-usul Dan Kewenangan Lokal Berskala Desa.

Sarjono, Haryadi dan Winda Julianita. 2013. SPSS Vs LISREL Sebuah Pengantar, Aplikasi untuk Riset. Cetakan Kedua. Salemba Empat. Jakarta.

Sujarweni, V. Wiratna. 2015. Akuntansi Desa Panduan Tata Kelola Keuangan Desa. Pustaka Baru Press. Yogyakarta.

Sujarweni, V. Wiratna. 2015. Akuntansi Sektor Publik. Pustaka Baru Press. Yogyakarta.

UU Nomor 32 Tahun 2004 tentang Pemerintah Daerah.

UU Nomor 6 Tahun 2004 Tentang Desa.

Peraturan Pemerintah Republik Indonesia Nomor 43 Tahun 2014 Tentang Peraturan Pelaksanaan

Undang-Undang Nomor 6 Tahun 2014 Tentang Desa.

Purwanto. 2011. Statistika Untuk Penellitian. Pustaka Belajar. Yogyakarta.

Wibowo. 2016. Manajemen Kinerja. Edisi Kelima. Rajawali Pers. Jakarta.

Wulandari, Agnes. 2017. Analisis Kinerja Pada Perangkat Daerah Menggunakan Balanced Scorecard (Studi Kasus Di Biro Umum Sekretariat Daerah Provinsi Kalimantan Tengah). Skripsi. Program Akuntansi Universitas Sanata Dharma. Yogyakarta.

Yuliansyah dan Rusmianto. 2018. Akuntansi Desa. Salemba Empat. Jakarta. 